اثر روشهاى مختلف يرايمينت بر قابليت انباردارى و جوانهزنى بذر كلزا (Brassica napus)$$
\text { لاين كرج ب در شرايط تنش شورى }
$$

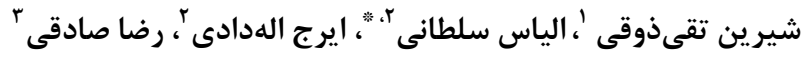$$
\text { ' دانشجوى كارشناسى ارشد كروه زراعت و اصلاح نباتات، دانشخاه تهران، يرديس ابوريحان }
$$

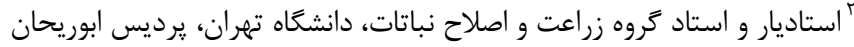

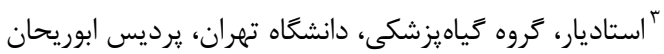

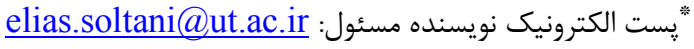

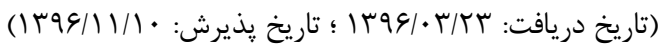

جكيده

در اين تحقيق اثر روشهاى مختلف يرايمينغ بر درصد و سرعت جوانهزنى كلزا در شرايط تنش شورى و تعيين قابليت انباردارى بذرهاى يرايمشده مطالعه شد. به اين منظور سه آزمايش بهصورت مجزا آنائ انجام شد كه

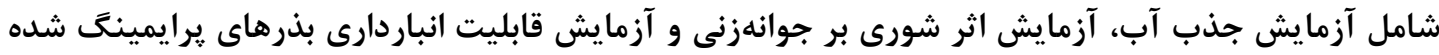

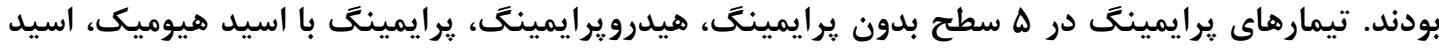

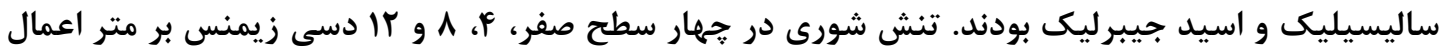

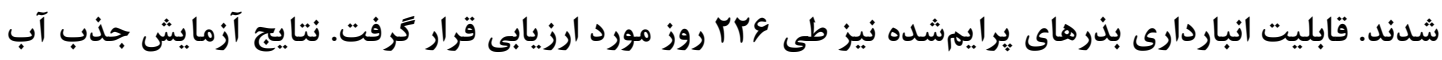

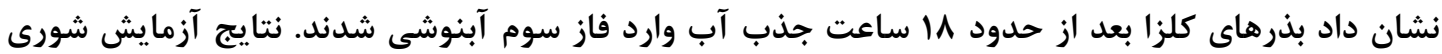

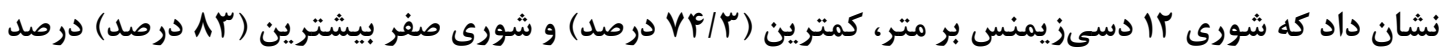

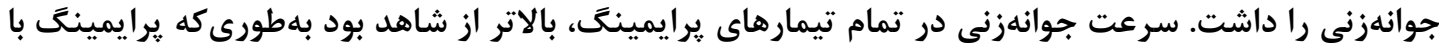

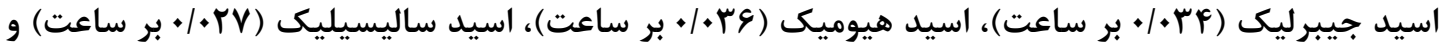

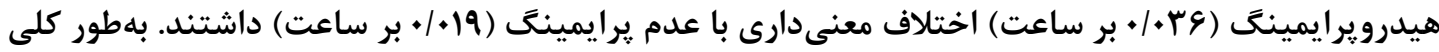

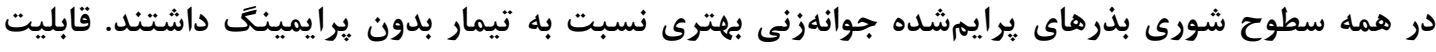

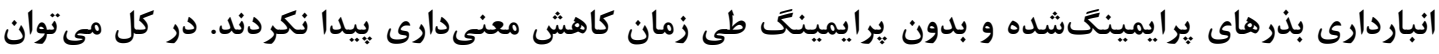

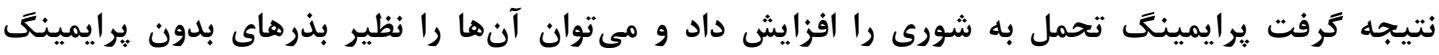
نتخهدارى كرد.

وازههاى كليدى: اسيد جيبرليك، اسيد ساليسيليك، اسيد هيوميك، تنش، هيدرويرايمينگ جنبه هاى نو آورى:

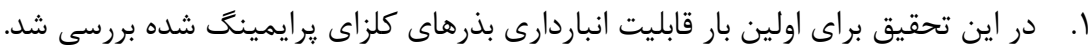

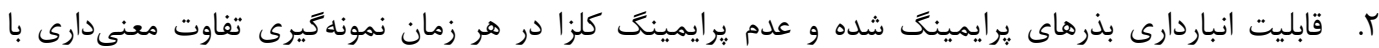
يكديخر نداشتند (بهاستثناى اسيد هيوميك).

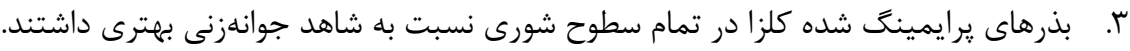

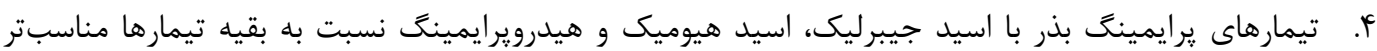




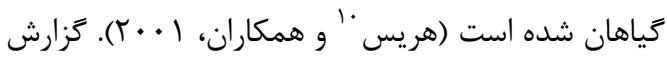

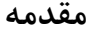
شده است كه اين فن باعث افزايش دامنه جوانهزنى بذرها در شرايط محيطى تنشزا از قبيل تنش شورى،

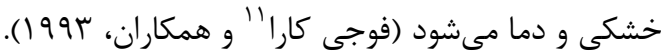

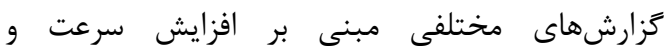
يكنواختى جوانهزنى و سبز شدن در تنشهاى مختى مختلف محيطى از قبيل شورى و خشكى با استفاده از تيمار يرايمينگ در گياهان مختلف وجود دارد (هريس و

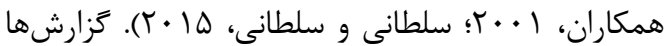

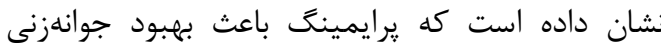

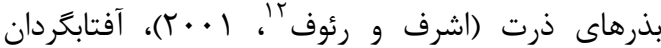

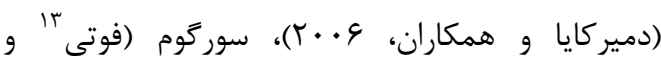

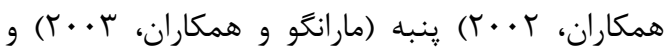

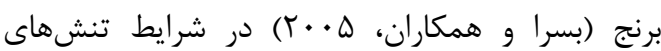

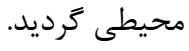

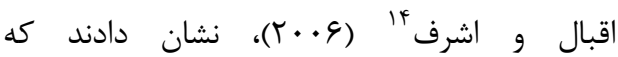

هيدرويرايمينگ بذر كندم موجب افزايش رشد كياه در شرايط تنش شورى در مقايسه با بذور بدون يرايمينَ

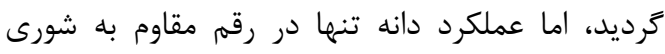

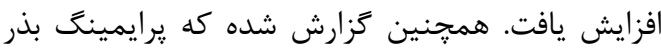

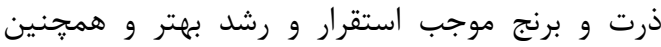

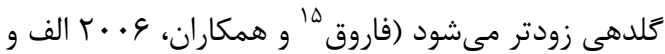

سلطانى و سلطانى (Q) (Y) در يك متآناليز نشان دادند كه در بين تيمارهاى مختلف برايمينگ در كياهان

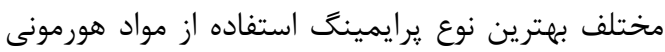
بود و بعد از آن استفاده از هيدرويرايمينگ بيشت بيشترين

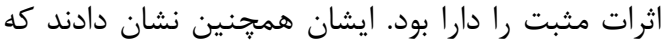

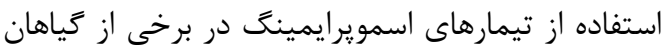
به دليل سميتى كه در بذر ايجاد مى كند مىتواند اثرات

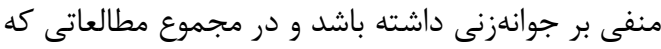

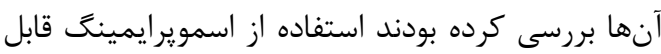
توصيه نبود. اطلاعات اندكى روى قابليت انباردارى

\footnotetext{
${ }^{10}$ Harris

${ }^{11}$ Fujikara

${ }^{12}$ Ashraf and Rauf

${ }^{13}$ Foti

${ }^{14}$ Iqbal and Ashraf

${ }^{15}$ Farooq
}

جوانهزنى مرحلهاى از رشد است كه بهشدت تحت

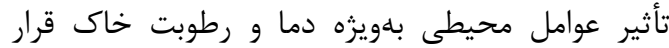

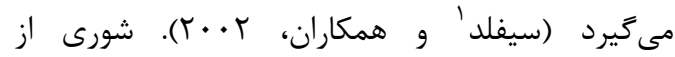
تنشهاى مهم محيطى است كه عملكرد محصولات

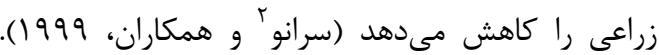
مرحله جوانهزنى يكى از مراحل حساس رشد رئ رياه به

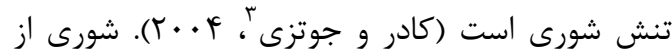
طريق كاهش يتانسيل آب و سميت يونهاى سديم و و كلر و همجنين كاهش يونهاى غذايى موردنياز كياه از

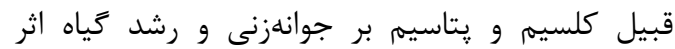

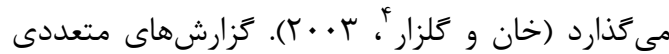

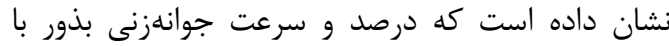

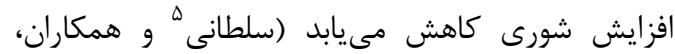
. ( $) \cdot(1)$

در شرايط تنشهاى محيطى يكى از راههاى افزايش

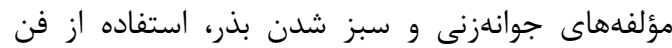

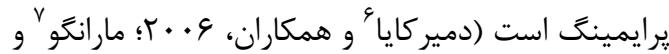

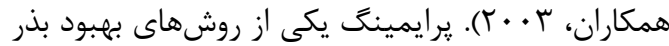

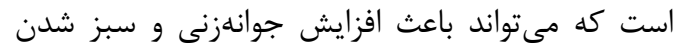
بذر شود. استفاده از روش يرايمينَ يكى إنى إز روشهاى بهبود كاركرد بذر و افزايش كيفيت بذر در شرايط

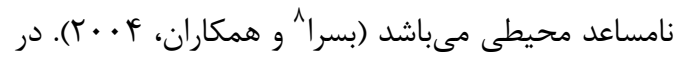

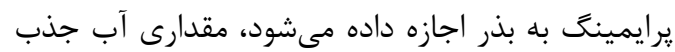
كنند، بلهورى كه مراحل اوليه جوانهزنى (شامل فعال

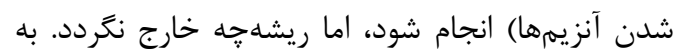
عبارت بهتر در اين روش، بذرها تا مرحله دوم آبنوشى آنى

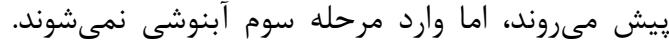

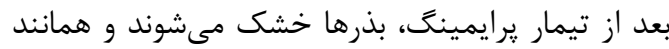

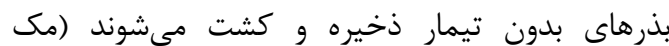

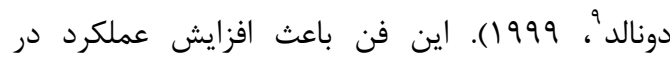

\footnotetext{
${ }^{1}$ Seefeldt

${ }^{2}$ Serrano

${ }^{3}$ Kader and Jutzi

${ }^{4}$ Khan and Gulzar

${ }^{5}$ Soltani

${ }^{6}$ Demir Kaya

${ }^{7}$ Murungu

${ }^{8}$ Basra

${ }^{9}$ McDonald
} 
اثر يرايمينَ بر جوانهزنى كلزا در شرايط تنش شورى بررسى شد. اين آزمايش بلهصورت فاكتوريل در قالب

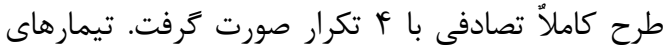

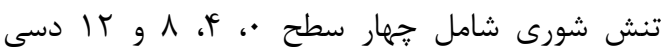
زيمنس بر متر و تيمار يرايمينگ در ه سطح شامل

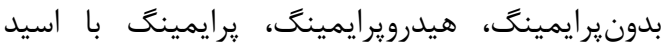

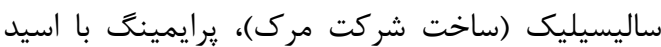
جيبرليك (ساخت شركت سيگما) و يرايمينَ با باسيد اسيد هيوميك (ساخت شركت بيشخام راهكار شريف) بودند.

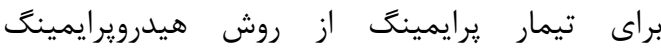
(يرايمينگ بذرها با استفاده از آب) بيشنههاد شده توسط

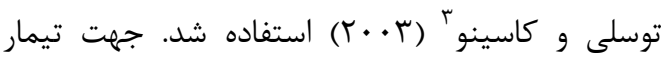
يرايمينگ بذرها با اسيد ساليسيليك ا ميلىمولار، 1ץ / • گرم اسيد ساليسيليك در يك ليتر آب مقطر

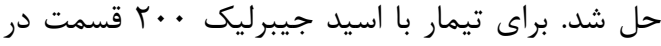

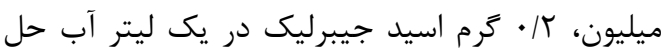

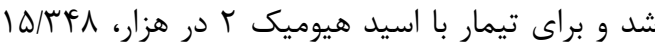
ميلىليتر اسيد هيوميك بار بـ با يكى ليتر آب مقطر

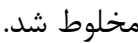

در آزمايش تنش شورى در هر تكرار از هر تيمار

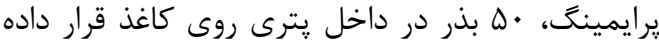

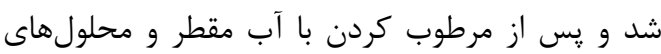

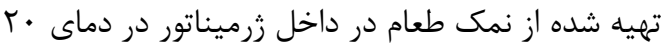

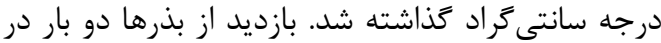
روز صورت گرفت و معيار بذور جوانهزده خروج ريشه خها،ه، بهاندازه r ميلىمتر يا بيشتر بود. در طول آزمايش (IF) روز) در صورت نياز به كاغذ آب مقطر و محلولهاى تهيه

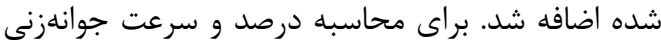
بذرها از برنامه Germin² استفاده شد كه اين برنامه

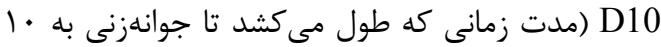

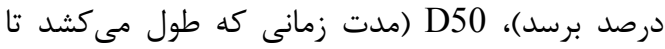

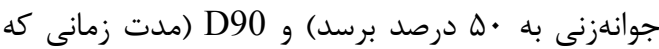

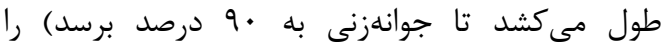
محاسبه مى كند. سرعت جوانهزنى (در ساعت) از طريق

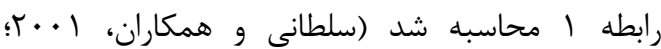
سلطانى و همكاران، سا • (广):

R50=1/D50
بذرهاى يرايمينَ شده وجود دارد كه از جمله آنها

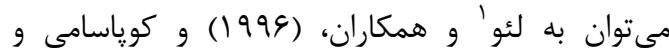

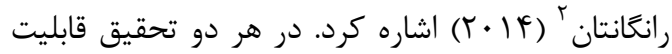
انباردارى بذرهاى يرايمينگ شده طى زمان تغيير

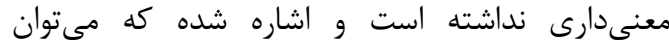

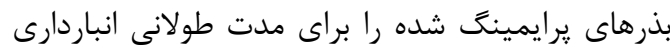

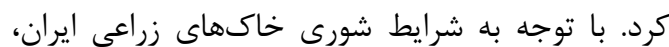
اهداف اين تحقيق عبارت بودند از: (1) بررسى روند

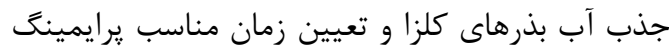

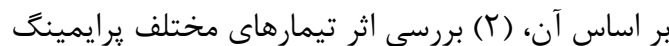

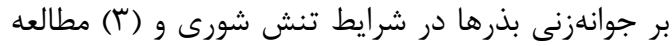
قابليت انباردارى بذرهاى يرايمينگشدها.

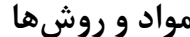

اين يزوهش در سال هو؟ा در دانشكاه تهران، برديس ابوريحان انجام شد. اين تحقيق بهصورت سه دانه

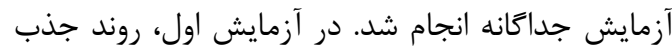

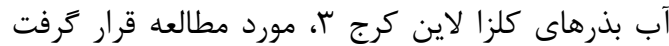

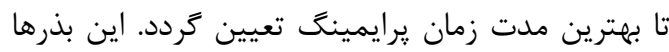

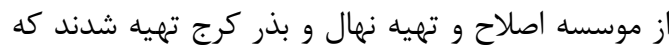
در سال هوبا برداشت شده بودند. اين لاين يك لاين

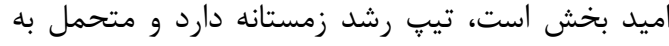
خشكى است. براى تعيين مدت زمان آبنوشى ابتدا وزن

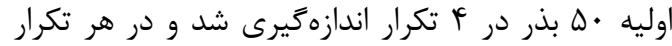

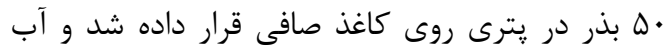

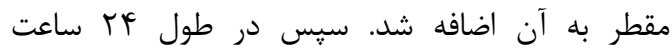

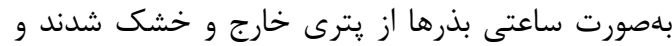

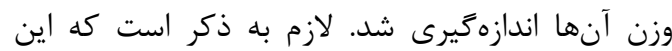
آزمايش دو بار تكرار شد تا دقت دادهها افزايش يابد وإند

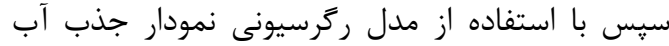
رسم شد و زمان خروج ريشهجه براى انجام يرايمينَ

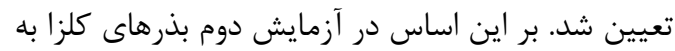
مدت • إساعت در آب مقطر، اسيد ساليسيليك، اسيد

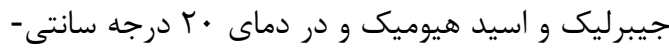

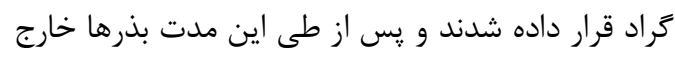

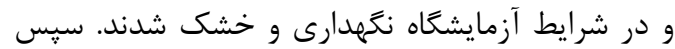

\footnotetext{
${ }^{1}$ Liu

${ }^{2}$ Kuppusamy and Ranganathan
} 
در اكثر مطالعات مربوط به يرايمينگ بذر بدون توجه به منحنى جذب آب و فقط با قرار دادن ساعتهاى مختلف يرايمينگ اقدام به انتخاب بهترين

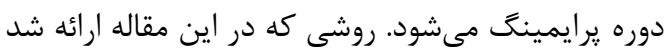

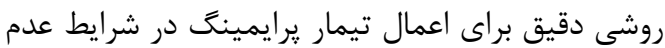

$$
\text { كنترل در جذب آب مى دياشد. }
$$

به اين ترتيب مىتوان زمان دقيق براى رسيدن به

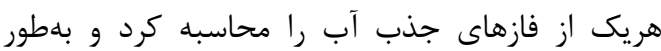

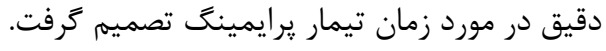

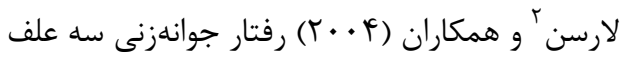

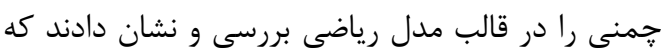

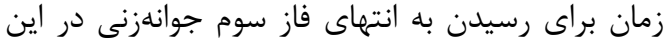

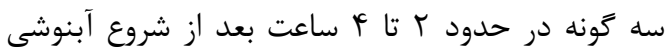

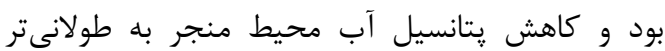
شدن فاز دوم جوانهزنى ترديد و در برخى إنى إز تيمارها

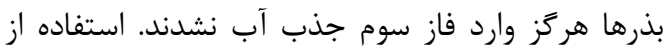

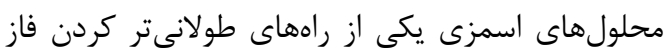

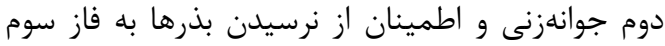

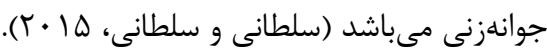

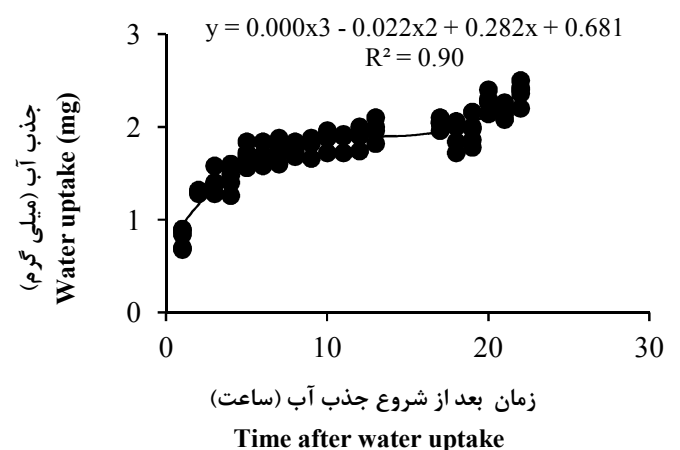

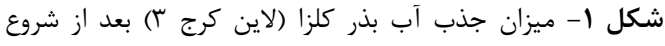

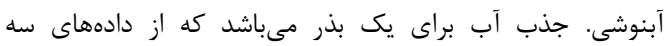

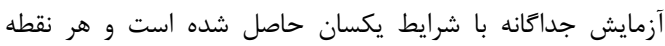

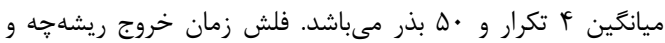

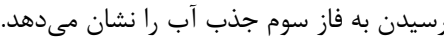

Figure 1. Water uptake of rapeseed (Karaj 3, line) after starting imbibition. Water uptake is shown for one seed, measured from three separate experiments with the same condition and each point being an average of 4 replications and 50 seeds. The arrow shows radicle emergence time and phase 3 of water uptake.

${ }^{2}$ Larsen

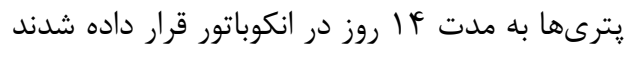

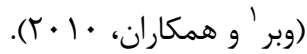

در آزمايش سوم قابليت انباردارى بذرهاى برايمينَ

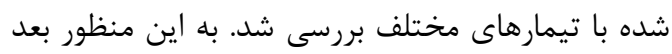

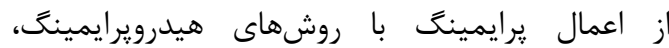
يرايمينَ با اسيد ساليسيليك، يرايمينگ با اسيد إيديد

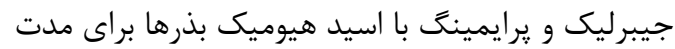

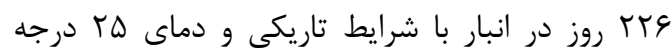

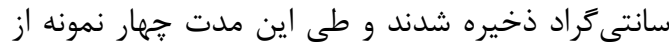

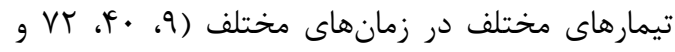

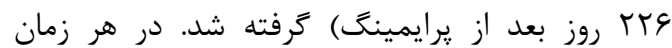
نمونه گيرى در هر تكرار و هر تيمار •له بذر در داخل سه

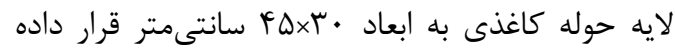

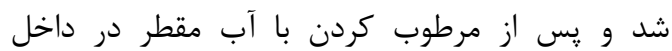

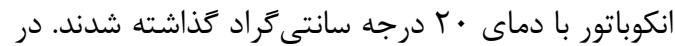

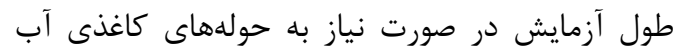

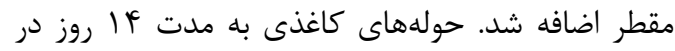

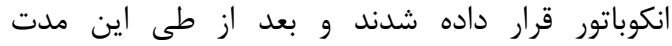
كياهجههاى طبيعى و غيرطبيعى و تعداد كل بذرهاى جوانهزده محاسبه كرديد. تجزيه آمارى با استفاده از برنامه آمارى SAS و

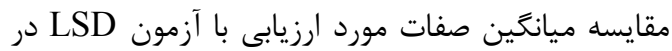
سطح احتمال ه درصد انجام ترديد.

نتايج و بحث

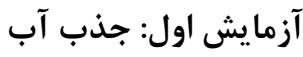

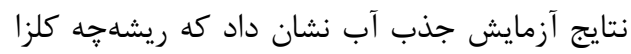

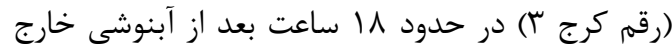

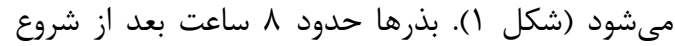

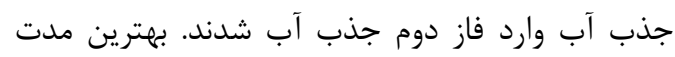
زمان براى يرايمينگ بذرها زمانى است كه بذرها در فاز

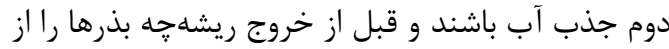

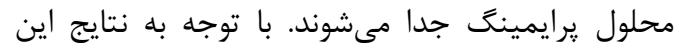

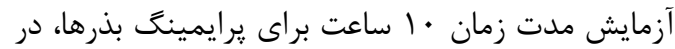

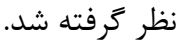

\footnotetext{
${ }^{1}$ Weber
} 
سرعت جوانهزنى نيز روند مشابهى با درصد جوانهزنى داشت و با افزايش شورى سرعت جوانهزنى

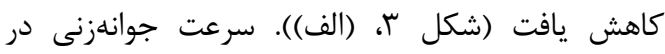
بذرهاى يرايمينَ شده نسبت به شاهد بيشتر بود. در

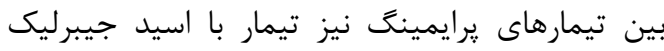

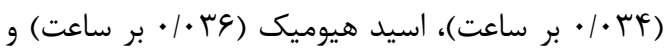

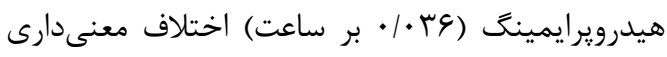
با عدم يرايمينَ (19 • • • بر ساعت) و يرايمينَ با اسيد ساليسيليك (rV • • • بر ساعت) داشتند (شكل rا، (ب)). نتايج آزمايش نشان داد كه با افزايش شدت شورى زمان تا شروع جوانهزنى بهطور معنى دارى افزايش خواهد يافت

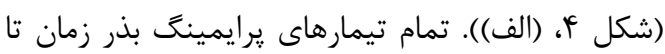

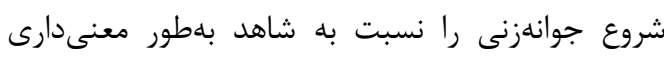

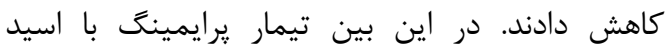
هيوميك كمترين زمان تا شروع جوانهزنى (11/11)

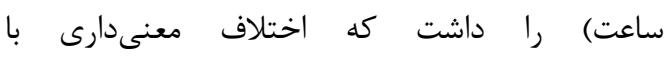

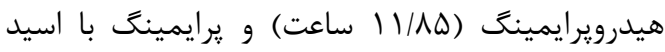

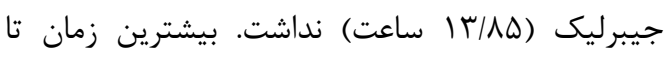
شروع جوانهزنى در تيمار شاهد (rV/TV ساعت) مشاهده شد (شكل أ، (ب)).

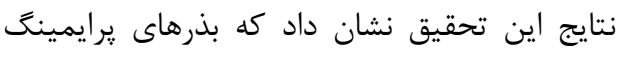

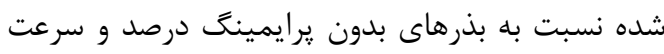

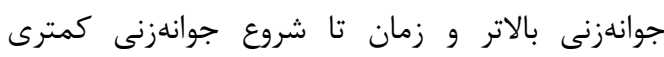
داشتند. زَارشهاى متعددى در اين زمينه وجود دارن دارد كه نشان مى دهد، بذرهايى كه رشد اوليه خود را سريعتر آغاز مى كنند در نتيجه كياهجههاى قوىترى نيز توليد خواهند كرد و در نهايت درصد سبزشدن و استقرار بالاترى نيز خواهند داشت (خواجهحسينى ' و و همكاران،

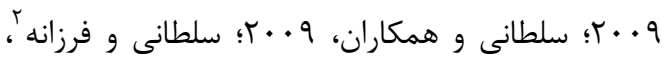

.$(r \cdot 14$

شرايط تنشهاى محيطى مىتواند باعث كاهش درصد و سرعت سبزشدن شود كه اثر آن روى بذرهايى با قدرت يايينتر بيشتر خواهد بود و يرايمينگ بذر مىتواند باعث

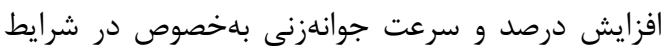
تنشهاى محيطى شود (سلطانى و سلطانى، ها • (Y).

\footnotetext{
${ }^{1}$ Khajeh-Hosseini

${ }^{2}$ Soltani and Farzaneh
}

روشهاى ديخرى نظير ״رايمينَ بذرها در دماى يايين و يا محدود كردن زمان زيرايمينگ مىتواند از رسيدن بذرها به فاز سوم جوانهزنى و خروج ريشه ممانعت نمايد.

\section{آزمايش دوم: اثر شورى بر جوانهزنى} با توجه به جدول تجزيه واريانس اثرات شورى آرى و و

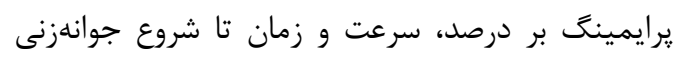

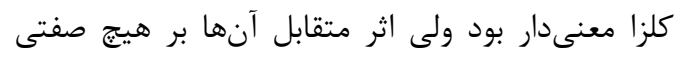
معنى دار نبود (جدول (1). نتيجه برشدهنى اثرمتقابل

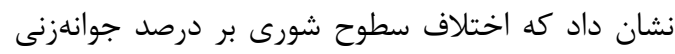
بذرها در شرايط يرايمينَ با تيمارهاى مختلف معنى دار

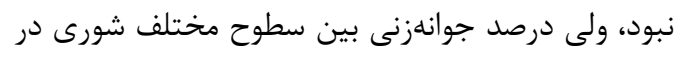

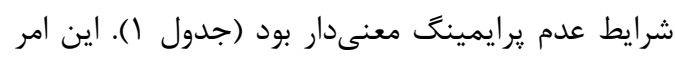
حاكى از اين است كه تيمارهاى يرايمينگ موجب افزايش درصد جوانهزنى شده است و در نتيجه اثر شورى إين بر درصد جوانهزنى را تا حد زيادى كاهش داده داست است.

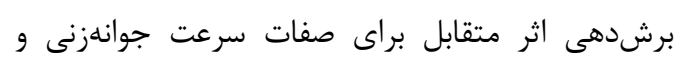
زمان تا شروع جوانهزنى نشان داد كه بين سطوح مختلف دئف شورى در همه تيمارهاى يرايمينَ اختلاف معنى دارى وجود داشته است (جدول ()). شورى درصد جوانهزنى را كاهش داد و با افزايش سطوح شورى كاهش درصد جوانهزنى شديدتر شد بهطورى كه اختلاف درصد جوانهزنى در شورى لـ دسىزيمنس بر متر (س/Y

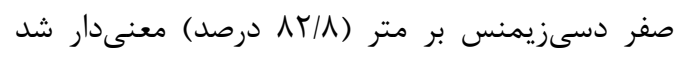
(شكل ז، (الف)). در بين تيمارهاى : يرايمينگ تيمار

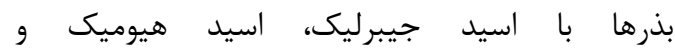

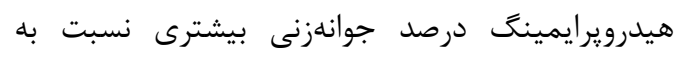

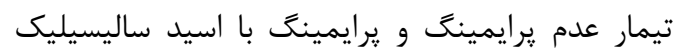
داشتند.

بهعنوان مثال، در شرايط هيدرويرايمينگ، پيرايمينَ

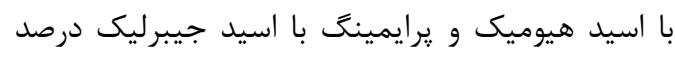

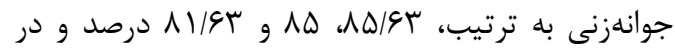
شرايط يرايمينگ با اسيد ساليسيليك و شاهد در صر صد

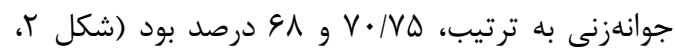




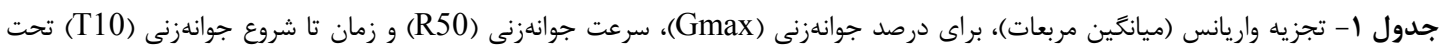

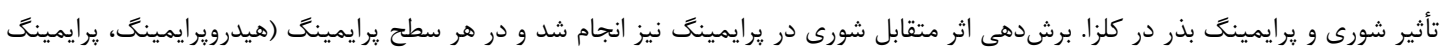

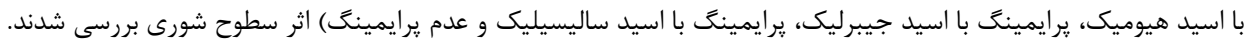

Table 1. Analysis of variance (mean squares) for germination percentage (Gmax), germination rate (R50), and onset of germination (T10) as affected by salinity and seed priming in rapeseed. The interaction slicing of salinity and priming effects was conducted and salinity effect was investigated for each level of priming (hydropriming (Hyd), priming with humic acid (HA), priming with salicylic acid (SA) and priming with gibberellic acid (GA) and no priming $(\mathrm{C})$ ).

\begin{tabular}{|c|c|c|c|c|}
\hline $\begin{array}{l}\text { منابع تغييرات } \\
\text { S.O.V }\end{array}$ & $\begin{array}{l}\text { درجه آزادى } \\
\text { D.f. }\end{array}$ & $\begin{array}{l}\text { درصد جوانهزنى } \\
\text { Gmax }\end{array}$ & $\begin{array}{l}\text { سرعت جوانهزنى } \\
\text { R50 }\end{array}$ & زمان تا شروع جوانهزنى \\
\hline $\begin{array}{l}\text { يرايمينَ } \\
\text { Priming }\end{array}$ & 4 & $1090.58^{* * *}$ & $0.00092^{\text {**.* }}$ & $675.58^{\text {ma }}$ \\
\hline $\begin{array}{c}\text { تنش شورى } \\
\text { Salinity Stress }\end{array}$ & 3 & $245.83^{\text {䇏 }}$ & $0.0006^{\text {总 }}$ & $518.31^{\text {稳 }}$ \\
\hline $\begin{array}{c}\text { اثر متقابل } \\
\text { Interaction }\end{array}$ & 12 & $43.87^{\mathrm{n} . \mathrm{s}}$ & $0.000024^{\mathrm{n} . \mathrm{s}}$ & $20.46^{\text {n.s }}$ \\
\hline $\begin{array}{l}\text { خ } \\
\text { (E) }\end{array}$ & 60 & 60.87 & 0.000027 & 20.05 \\
\hline
\end{tabular}

برشدهى اثر متقابل

Slicing of interaction effect

\begin{tabular}{|c|c|c|c|c|}
\hline اسيد جيبرليك GA & 3 & $124.25^{\mathrm{n} . \mathrm{s}}$ & $0.00016^{* *}$ & $137.2^{\text {wh }}$ \\
\hline HA اسيد هيوميك & 3 & $23.33^{\mathrm{n} . \mathrm{s}}$ & $0.00013^{\text {**: }}$ & $146.38^{* * *}$ \\
\hline Hyd هيدرويرايمينگ & 3 & $16.92^{\mathrm{n} . \mathrm{s}}$ & $0.00015^{* * *}$ & $101.37^{\text {** }}$ \\
\hline اسيد ساليسيليك SA & 3 & $59.66^{\mathrm{n} . \mathrm{s}}$ & $0.0002^{\text {*n }}$ & $196.07^{\text {s." }}$ \\
\hline عدم يرايمينغ C & 3 & 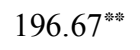 & $0.000074^{\text {n.s }}$ & $19.14^{\text {n.s }}$ \\
\hline
\end{tabular}

*, $* *$ indicate significance at $\mathrm{p}<0.05$ and $\mathrm{p}<0.01$, and ${ }^{\text {n.s }}$ indicate no significant

(الف) (الف)

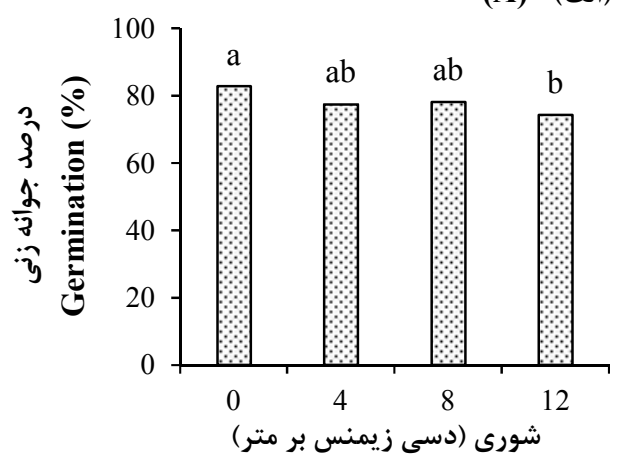

Salinity (dS/m)

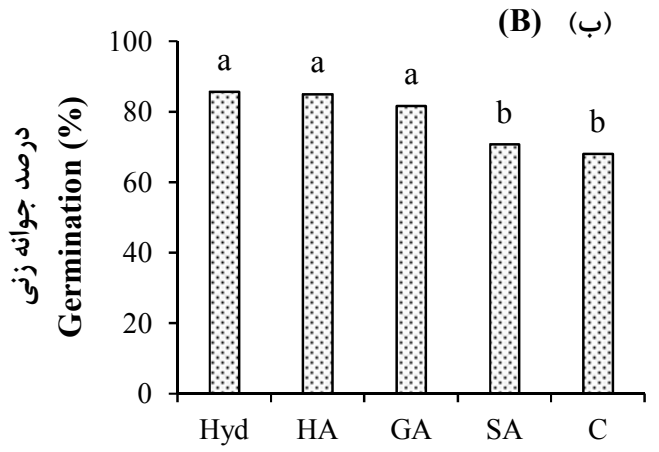

برايمينَ Priming

شكل r- اثر شورى بر درصد جوانهزنى بذرهاى كلزا (الف). اثر يرايمينَ بر درصد جوانهزنى بذر كلزا (ب). Hyd (HA هيدرويرايمينگ، HA

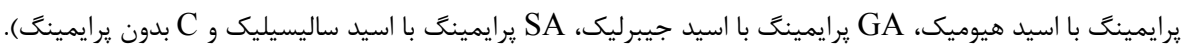

Figure 2. Effect of salinity on germination percentage of rapeseed seeds (A). Effect of priming on germination percentage of rapeseed seeds (B). (Hydropriming (Hyd); Humic acid (HA); Priming with salicylic acid (SA); Priming with gibberellic acid (GA); No-priming (C)). 

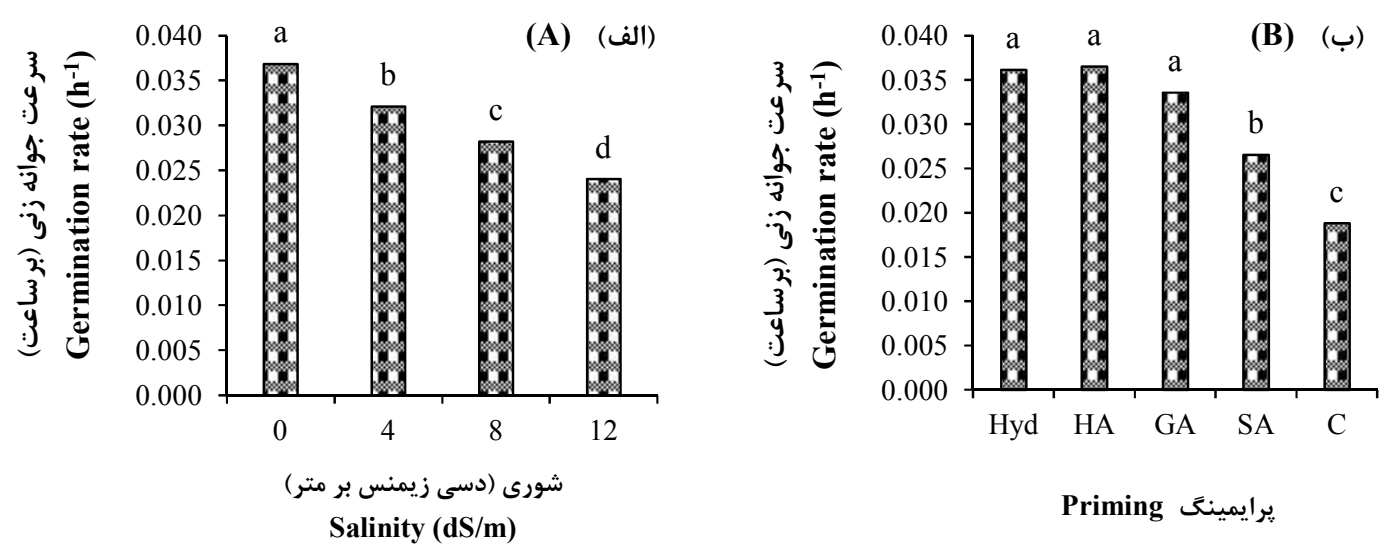

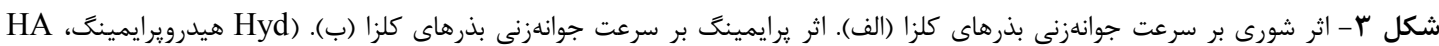

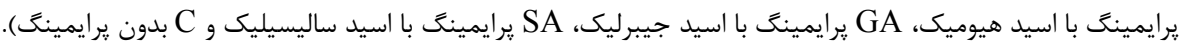

Figure 3. Effect of salinity on germination rate of rapeseed seeds (A). Effect of priming on germination rate of rapeseed seeds (B). (Hydropriming (Hyd); Humic acid (HA); Priming with salicylic acid (SA); Priming with gibberellic acid (GA); No-priming (C)).
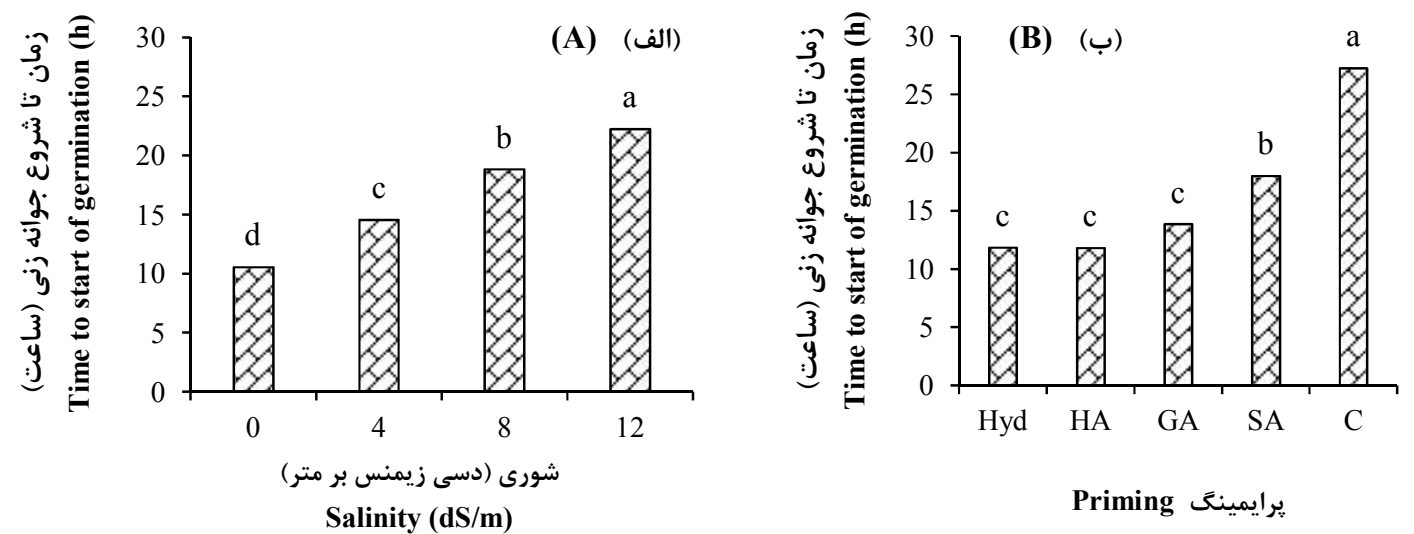

شكل F- اثر شورى بر زمان تا شروع جوانهزنى بذرهاى كلزا (الف). اثر برايمينگ بر زمان تا شروع جوانهزنى بذرهاى كلزا (ب). (Hyd

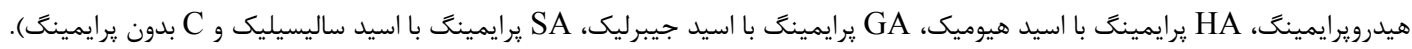
Figure 4. Effect of salinity on onset of germination of rapeseed seeds (A). Effect of priming on onset of germination of rapeseed seeds (B). (Hydropriming (Hyd); Humic acid (HA); Priming with salicylic acid (SA); Priming with gibberellic acid (GA); No-priming (C)).

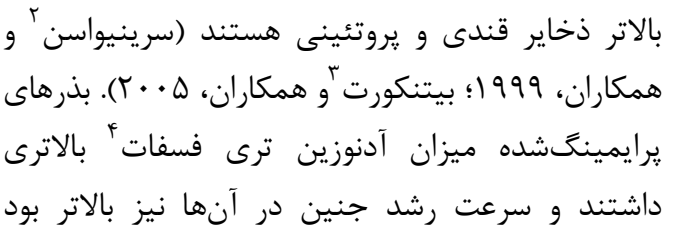

${ }^{2}$ Srinivasan

${ }^{3}$ Bittencourt

${ }^{4}$ ATP

$$
\begin{aligned}
& \text { دلايل متعددى براى بهبود جوانهزنى و استقرار } \\
& \text { بذرهاى يرايمينگشده ارائه شده است. زمانى كه بذرها برائ. } \\
& \text { آب جذب مى كنند تغييرات فيزيولوزيكى و بيوشيميايى } \\
& \text { در آنها رخ مي دهد (خان ' بو (199). }
\end{aligned}
$$

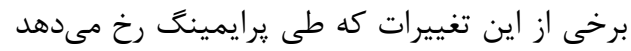

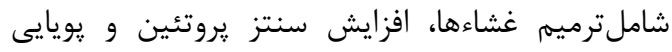

${ }^{1}$ Khan 


\section{آزمايش سوم: قابليت انباردارى بذرهاى

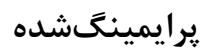

نتيجه تجزيه ركرسيون اين آزمايش نشان داد كه

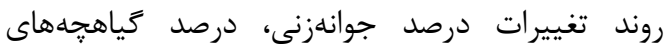

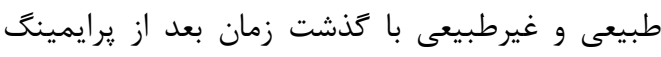

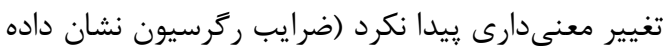

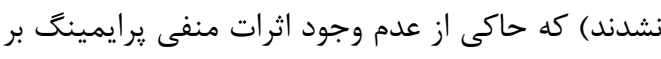

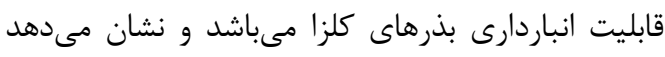

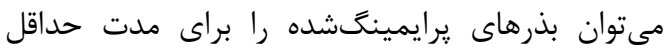

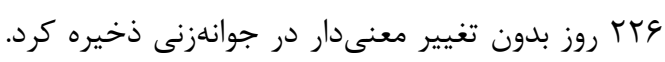

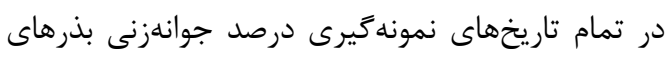

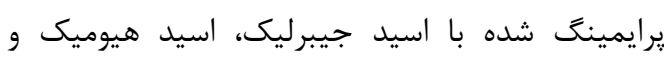

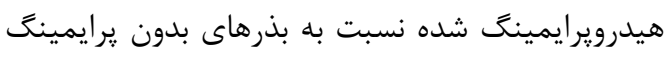

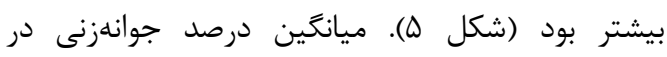

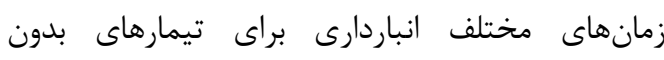

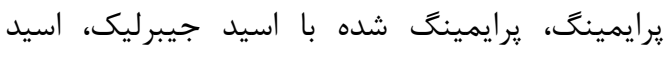

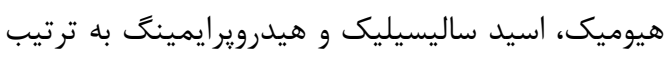

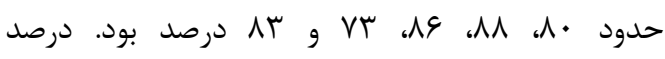

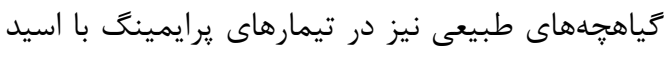

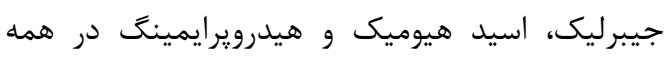

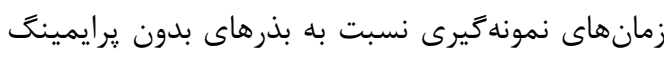

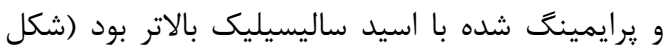

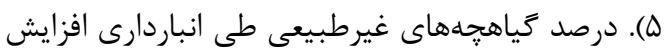

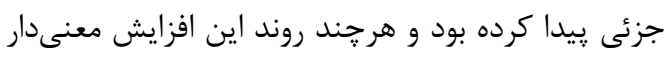

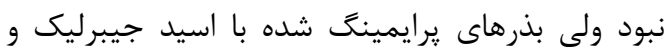

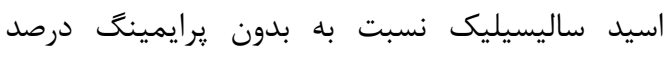

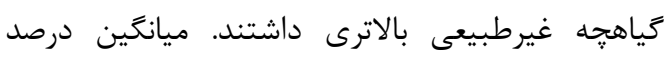

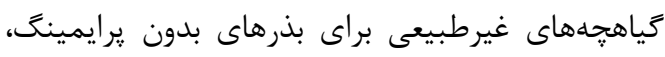

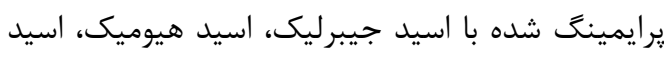

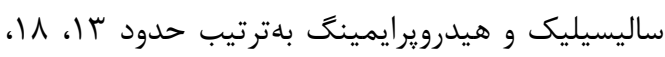

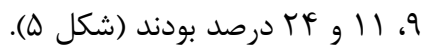
زوال بذر منجر به كاهش كيفيت بذر، قدرت حيات،

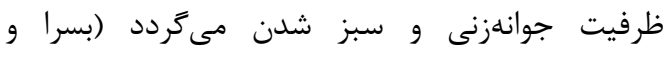

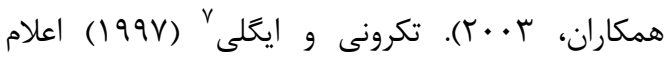

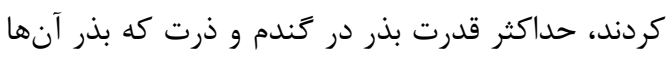

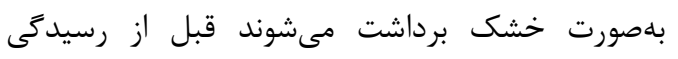

\footnotetext{
${ }^{7}$ Tekrony and Egli
}

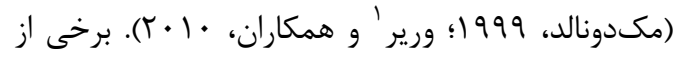

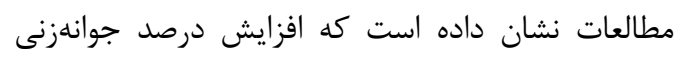

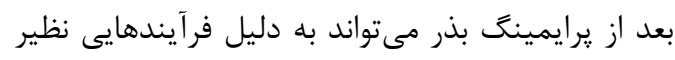

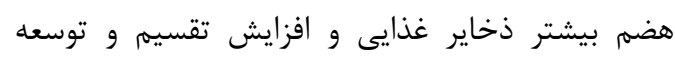

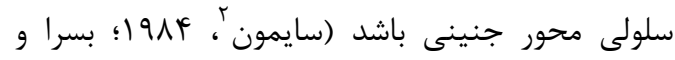

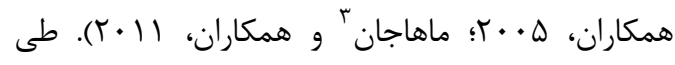

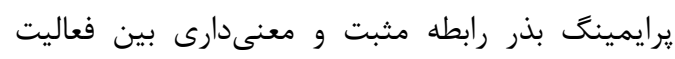

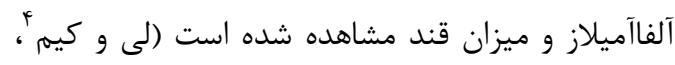

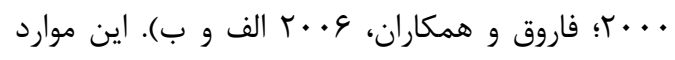

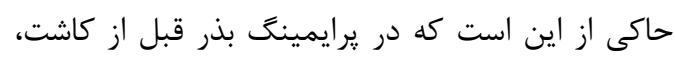

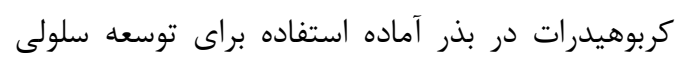

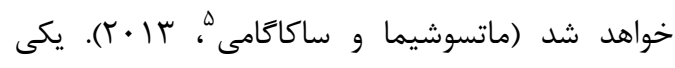

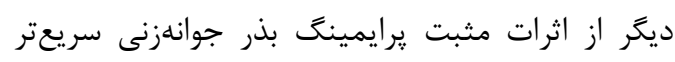

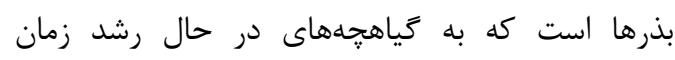

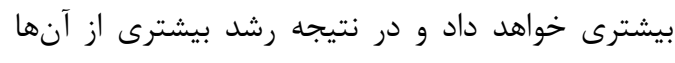

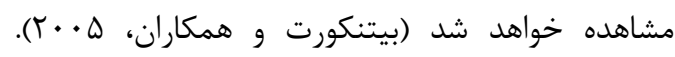

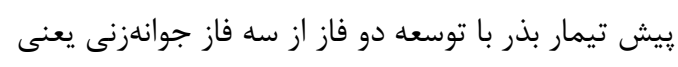

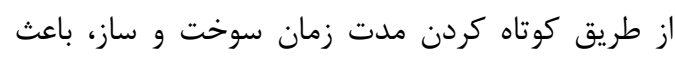
تسريع جوانهزنى مىشود. هاس و و سانگ

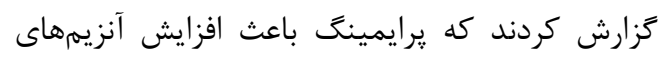

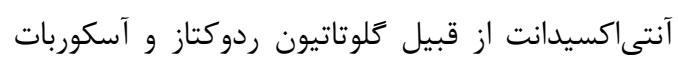

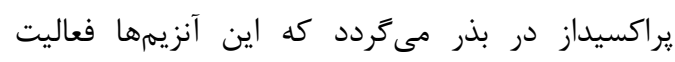

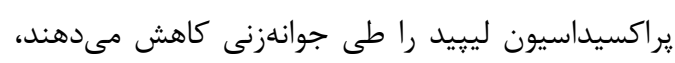

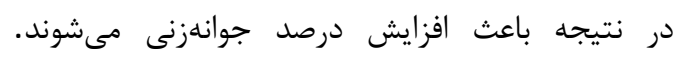

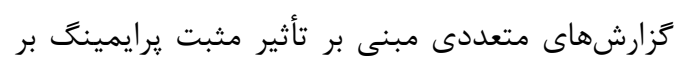

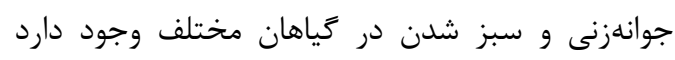

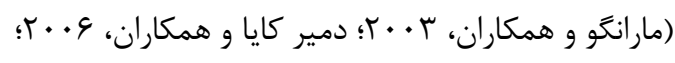

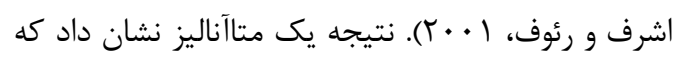

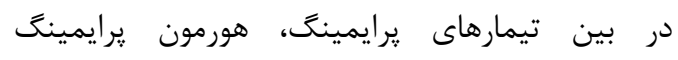

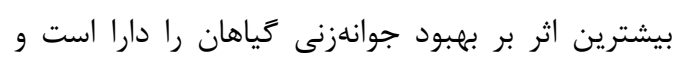

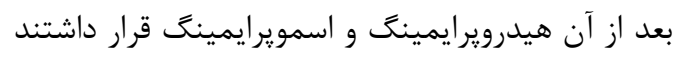
(سلطانى و سلطانى، ها • (Y).

\footnotetext{
${ }^{1}$ Varier

${ }^{2}$ Simon

${ }^{3}$ Mahajan

${ }^{4}$ Lee and Kim

${ }^{5}$ Matsushima and Sakagami

${ }^{6}$ Hus and Sung
} 

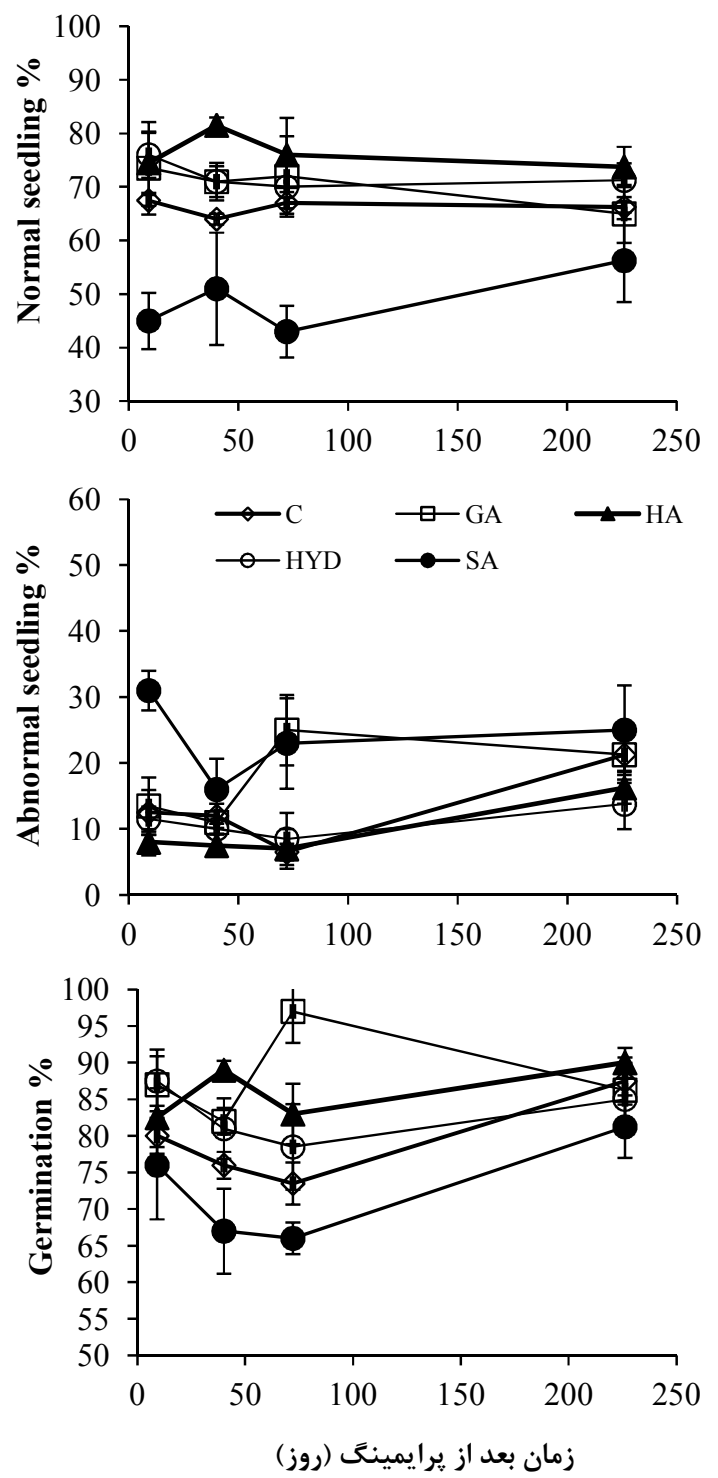

Time after priming (day)

شكل هـ - روند تغييرات درصد جوانهزنى، درصد كياهجههاى طبيعى و

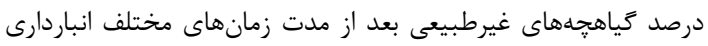

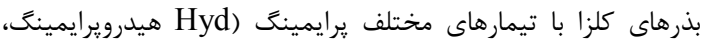

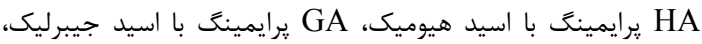

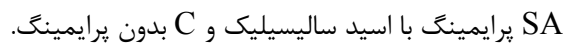

Figure 5. Changes of germination percentage, normal seedling percentage, and abnormal seedling percentage after different rapeseed seed storage times with different priming treatments (hydropriming (Hyd), humic acid (HA), priming with salicylic acid (SA), priming with gibberellic acid (GA), and nonpriming $(\mathrm{C}))$.
فيزيولوزيك حاصل مىشود، اما مسلماً قدرت بذر در طول دوره انباردارى در همين وضعيت باقى نمىماند

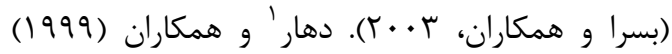
اعلام كردند كه شرايط انبارى متفاوت مىتواند باعث ايجاد اختلافهاى معنىدارى در جوانهزنى و سبز شدن كياهان شود. با زوال بذر، قدرت بذر اولين جزء از كيفيت بذر است كه كاهش مىيابد و به دنبال آن ظرفيت

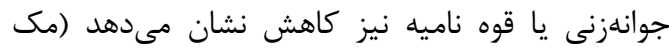

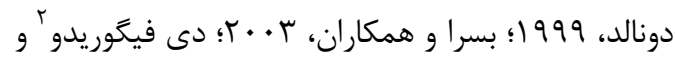

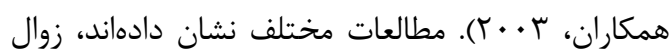
بذر بهطور معنى دارى جوانهزنى (بسرا و همكاران،

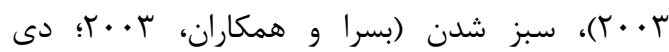

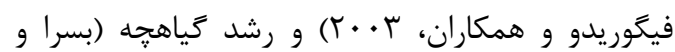

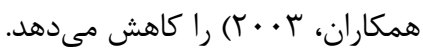

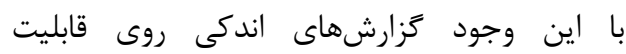

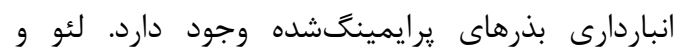

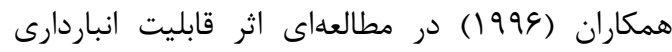
بذرهاى اسمويرايمينت شده گوجهفرنگى را بررسى و مشاهده كردند كه بعد از له ماه انبارى هنوز اثرات مثبت بـديت

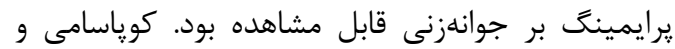

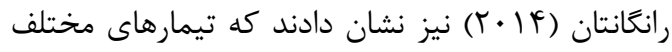
يرايمينغ بذر اكرا (Abelmoschus esculentus) نتيجه متفاوتى بر قابليت انباردارى بذرها داشت.

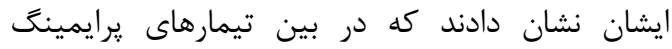

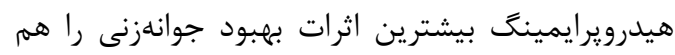

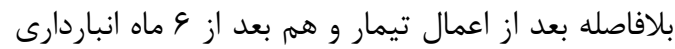

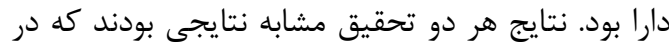
اين تحقيق به دست آمد، هرجند زمانهاى طولانىتر انبارى شايد نتايج متفاوتترى ايجاد كند. همانطور كه در اين تحقيق ديده شد در تيمار پرايمينگ با اسيد جيبرليك درصد زياهجههاى غيرطبيعى نسبت به تيمار

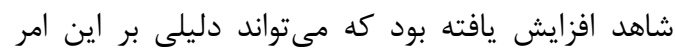
باشد كة زمانهاى طولانىتر انبارى موجب كاهش كيفيت بذرهاى يرايمينگشده و شاهد خواهد شد و از

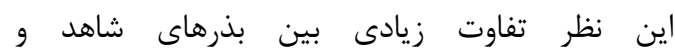

$$
\text { يرايمينَ تشده وجود ندارد. }
$$

\footnotetext{
${ }^{1}$ Dhar

${ }^{2}$ De Figueiredo
} 
جوانهزنى شد. نتايج نشان داد كه بذرهاى يرايمينگشده نتيجه گيرى

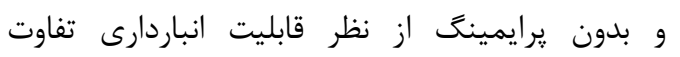
در مجموع از نتايج اين تحقيق مىتوان نتيجه كرفت آندي

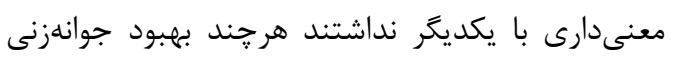

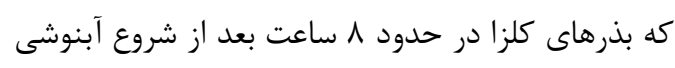

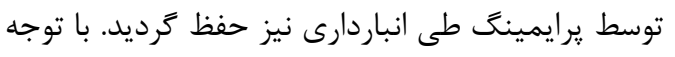

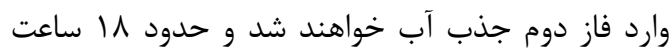

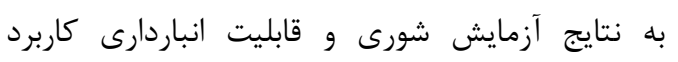

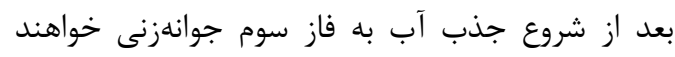

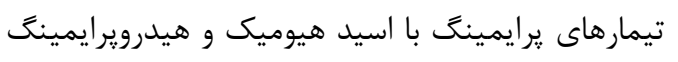

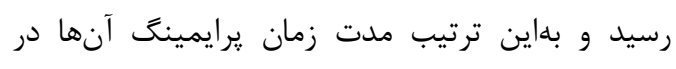

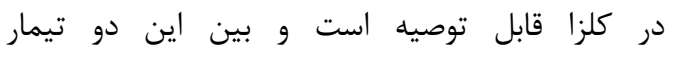

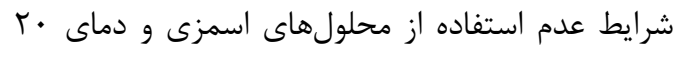

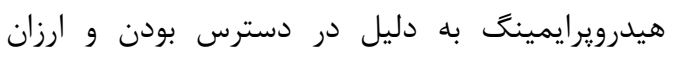

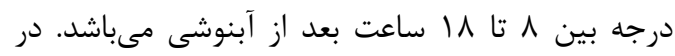
قيمتبودن تيمار مناسبترى خواهد بود دين دين دين

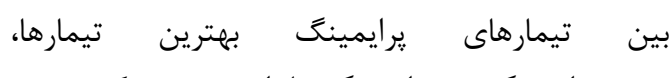

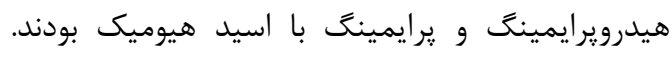

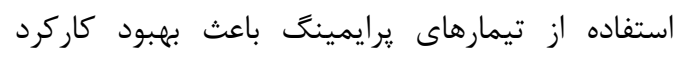

منابع

Ashraf, M., and Rauf, H. 2001. Inducing salt tolerate in maize (Zea mays L.) through seed priming with chloride salts: growth and ion transport at early growth stages. Acta Physiologiae Plantarum, 23(4): 407-414. https://doi.org/10.1007/s11738-001-0050-9

Basra, S.M.A., Ahmad, N., Khan, M.M., Iqbal, N., and Cheema, M.A. 2003. Assessment of cottonseed deterioration during accelerated ageing. Seed Science and Technology, 31(3): 531540. https://doi.org/10.15258/sst.2003.31.3.02

Basra, S.M.A., Ashraf, M., Iqbal, N., Khaliq, A., and Ahmad, R. 2004. Physiological and biochemical aspects of pre-sowing heat stress on cottonseed. Seed Science and Technology, 32(3): 765-774. https://doi.org/10.15258/sst.2004.32.3.12

Basra, S.M.A., Farooq, M., and Tabassum, R. 2005. Physiological and biochemical aspects of seed vigour enhancement treatments in fine rice (Oryza sativa L.). Seed Science and Technology, 33(3): 623-628. https://doi.org/10.15258/sst.2005.33.3.09

Bittencourt, M.L.C., Dias, D.C., Dias, L.A., and Araújo, E.F. 2005. Germination and vigour of primed Asparagus seeds. Scientia Agricola, 62(4): 319-324. https://doi.org/10.1590/S0103$\underline{90162005000400003}$

De Figueiredo, E., Albuquerque, M.C., and De Carvalho, N.M. 2003. Effect of the type of environmental stress on the emergence of sunflower (Helianthus annuus L.), soybean (Glycine max L.) and maize (Zea mays L.) seeds with different levels of vigor. Seed Science and Technology, 31(2): 465-479. https://doi.org/10.15258/sst.2003.31.2.23

Demir Kaya, M., Okçu, G., Atak, M., Çikili, Y., and Kolsarici, Ö. 2006. Seed treatment to overcome salt and drought stress during germination in sunflower (Helianthus annuus L.). European Journal of Agronomy, 24(4): 291-295. https://doi.org/10.1016/j.eja.2005.08.001

Dhar, U., Pangtey, Y.P.S., and Tewari, A. 1999. Seed deterioration studies in Indian butter tree (Aisandra butyracea (Roxb.) Baehni). Seed Science and Technology, 27(3): 963-968.

Farooq, M., Basra, S.M.A., Khalid, M., Tabassum, R., and Mahmood, T. 2006a. Nutrient homeostasis, metabolism of reserves and seedling vigor as affected by seed priming in coarse rice. Botany, 84(8): 1196-1202. https://doi.org/10.1139/b06-088

Farooq, M., Shahrzad, M., and Basra, A. 2006b. Priming of field-sown rice seed enhances germination, seedling establishment, allometry and yield. Plant Growth Regulation, 49(2-3): 285-294. https://doi.org/10.1007/s10725-006-9138-y 
Foti, S., Cosentino, S.L., Patane, C., and Agosta, G.M.D. 2002. Effects of osmoconditioning upon seed germination of sorghum (Sorghum bicolor L.) under low temperatures. Seed Science and Technology, 30(3): 521-533.

Fujikara, Y., Kraak, H.L., Basra, A.S., and Karssen, C.M. 1993. Hydropriming, a simple and inexpensive priming method. University Microfilms International, 300 North Zeeb Road, Box 91, Ann Arbor, MI 48106 (USA).

Harris, D., Pathan, A.K., Gothkar, P., Joshi, A., Chivasa, W., and Nyamudeza, P. 2001. On-farm seed priming: using participatory methods to revive and refine a key technology. Agricultural Systems, 69(1-2): 151-164. https://doi.org/10.1016/S0308-521X(01)00023-3

Hus, J.L., and Sung, J.M. 1997. Antioxidant role of glutathione associated with accelerated agina and hydration of triploid Watermelon seeds. Physiologa Plantarum, 100(4): 967-974. https://doi.org/10.1111/j.1399-3054.1997.tb00024.x

Iqbal, M., and Ashraf, M. 2006. Wheat seed priming in relation to salt tolerance: growth, yield and levels of free salicylic acid and polyamines. In Annales Botanici Fennici, 250-259.

Kader, M.A., and Jutzi, S.C. 2004. Effects of thermal and salt treatments during imbibition on germination and seedling growth of sorghum at $42 / 19^{\circ} \mathrm{C}$. Journal of Agronomy and Crop Science, 190(1): 35-38. https://doi.org/10.1046/j.0931-2250.2003.00071.x

Khajeh-Hosseini, M., Lomholt, A., and Matthews, S. 2009. Mean germination time in the laboratory estimates the relative vigour and field performance of commercial seed lots of maize (Zea mays L.). Seed Science and Technology, 37(2): 446-456. https://doi.org/10.15258/sst.2009.37.2.17

Khan, A.A. 1992. Preplant physiological seed conditioning. Jamck, M.J. (ed.), Horticultural reviews. John Wiley and Sons., New York, 131-181. https://doi.org/10.1002/9780470650509.ch4

Khan, M.A., and Gulzar, S. 2003. Germination responses of Sporobolus ioclados: A saline desert grass. Journal of Arid Environments, 53(3): 387-394. https://doi.org/10.1006/jare.2002.1045

Kuppusamy, N., and Ranganathan, U. 2014. Storage potential of primed seeds of okra (Abelmoschus esculentus) and beet root (Beta vulgaris). Australian Journal of Crop Science, 8(9): 1290-1297.

Larsen, S.U., Bailly, C., Côme, D., and Corbineau, F. 2004. Use of the hydrothermal time model to analyse interacting effects of water and temperature on germination of three grass species. Seed Science Research, 14(1): 35-50. https://doi.org/10.1079/SSR2003153

Lee, S.S., and Kim, J.H. 2000. Total Sugars, $\alpha$-Amylase Activity and Germination after Priming of Normal and Aged Rice Seeds. Korean Journal of Crop Science, 45(2): 108-111.

Liu, Y., Bino, R.J., van der Burg, W.J., Groot, S.P.C., and Hilhorst, H.W.M. 1996. Effects of osmotic priming on dormancy and storability of tomato (Lycopersicon esculentum Mill) seeds. Seed Science Research, 6(2): 49-55. https://doi.org/10.1017/S0960258500003020

Mahajan, G., Sarlach, R.S., Japinder, S., and Gill, M.S. 2011. Seed priming effects on germination, growth and yield of dry direct-seeded rice. Journal of Crop Improvement, 25(4): 409-417. https://doi.org/10.1080/15427528.2011.576381

Matsushima, K.I., and Sakagami, J.I. 2013. Effects of seed hydropriming on germination and seedling vigor during emergence of rice under different soil moisture conditions. American Journal of Plant Science, 4(8): 1584-1593. https://doi.org/10.4236/ajps.2013.48191

McDonald, M.B. 1999. Seed deterioration: physiology, repair and assessment. Seed Science and Technology, 27: 177-237. 


\section{تقى ذوقى و همكاران: اثر روشهاى مختلف يرايمينَ بر قابليت انباردارى و جوانهزنى بذر كلزا...}

Murungu, F.S., Nyamugafata, P., Chiduza, C., Clark, L.J., and Whalley, W.R. 2003. Effects of seed priming aggregate size and soil matric potential on emergence of cotton (Gossypium hirsutum L.) and maize (Zea mays L.). Soil and Tillage Research, 74(2): 161-168. https://doi.org/10.1016/j.still.2003.06.003

Seefeldt, S.S., Kidwell, K.K., and Waller, J.E. 2002. Base growth temperature, germination rate and growth response of contemporary spring wheat cultivars from the USA Pacific North West. Field Crop Research, 75: 47-52. https://doi.org/10.1016/S0378-4290(02)00007-2

Serrano, R., Macia, F.C., and Moreno, V. 1999. Genetic engineering of salt and drought tolerance with yeast regulatory genes. Scientia Horticulturae, 78(1-4): 261-269. https://doi.org/10.1016/S0304-4238(98)00196-4

Simon, E.W. 1984. Early events in germination. In: Murray, D.R. (ed.). Seed physiology: germination and reserve mobilization. Academic Press, Orlando, FL. 77-115. https://doi.org/10.1016/B978-0-12-511902-3.50008-7

Soltani, A., Galeshi, S., Zenali E., and Latifi, N. 2001. Germinating seed reserve utilization and growth of chickpea as affected by salinity and seed size. Seed Science and Technology, 30: 5160.

Soltani, E., Galeshi, S., Kamkar, B. and Akramghaderi, F. 2009.The effect of seed aging on seedling growth as affected by environmental factors in wheat. Research Journal of Environmental Science, 3: 184-192. https://doi.org/10.3923/rjes.2009.184.192

Soltani, E., Soltani, A. and Oveisi, M. 2013. Modeling Seed Aging Effect on Wheat Seedling Emergence in Drought Stress: Optimizing Germin Program to Predict Emergence Pattern. Journal of Crop Improvement, 15(2): 147-160. [In Persian with English Summary].

Soltani, E., and Farzaneh, S. 2014. Hydrotime analysis for determination of seed vigour in cotton. Seed Science and Technology, 42(2): 260-273. https://doi.org/10.15258/sst.2014.42.2.14

Soltani, E., and Soltani, A. 2015. Meta-analysis of seed priming effects on seed germination, seedling emergence and crop yield: Iranian studies. International Journal of Plant Production, 9(3): 413-432.

Srinivasan, K., Saxena, S., and Singh, B.B. 1999. Osmo- and hydropriming of mustard seeds to improve vigour and some biochemical activities. Seed Science and Technology, 27(2): 785-789.

Tekrony, D.M., and Egli, D.B. 1997. Accumulation of seed vigour during development and maturation. In Basic and applied aspects of seed biology, Springer, Dordrecht, 369-384. https://doi.org/10.1007/978-94-011-5716-2_ 41

Toselli, M.E., and Casenave, E.C. 2003. Water content and the effectiveness of hydro and osmotic priming of cotton seeds. Seed Science and Technology, 31(3): 727-735. https://doi.org/10.15258/sst.2003.31.3.21

Varier, A., Vari, A.K., and Dadlani, M. 2010. The subcellular basis of seed priming. Current Science, 99: 450-456.

Weber, E.A., Frick, K., Gruber, S., and Claupein, W. 2010. Research and development towards a laboratory method for testing the genotypic predisposition of oilseed rape (Brassica napus L.) to secondary dormancy. Seed Science and Technology, 38(2): 298-310.

https://doi.org/10.15258/sst.2010.38.2.03 


\title{
The Effects of Different Priming Methods on the Storability and Germination under Salinity Stress in Rapeseed (Brassica napus) Line Karaj 3
}

\author{
Shirin Taghi Zoghi ${ }^{1}$, Elias Soltani ${ }^{2, ~}{ }^{\text {, }}$, Iraj Alahdadi ${ }^{2}$, Reza Sadeghi $^{3}$ \\ ${ }^{1}$ MSc. Student of Agronomy, Department of Crop Science and Plant Breeding, Aboureihan \\ Campus University of Tehran, Pakdasht, Tehran, Iran \\ ${ }^{2}$ Assistant Professor and Professor, Department of Agronomy and Plant Breeding Sciences, \\ Aboureihan Campus University of Tehran, Pakdasht, Tehran, Iran \\ ${ }^{3}$ Assistant Professor, Department of Plant Entomology and Pathology, Aboureihan Campus \\ University of Tehran, Pakdasht, Tehran, Iran \\ ${ }^{*}$ Corresponding author, E-mail address: elias.soltani@ut.ac.ir
}

(Received: 13.06.2017; Accepted: 30.01.2018)

\begin{abstract}
This study was conducted to study the effects of different priming methods on germination rate and percentage under salinity stress and to determine the stability of primed seeds. In order to accomplish this, three different experiments were conducted separately, including the experiment of water uptake, the experiment of salinity stress, and the experiment of storability of primed seeds. Priming treatments were five levels of control (unprimed), hydropriming (Hyd), priming with humic acid (HA), priming with salicylic acid (SA) and priming with gibberellic acid (GA). Salinity stresses were four levels of $0,4,8$ and $12 \mathrm{ds} / \mathrm{m}$ of $\mathrm{NaCl}$. The stability of prime seeds was investigated over a period of 226 days after priming. The results of water uptake showed that rapeseeds entered into the third phase of water uptake after 18 hours of hydration. The results of the salinity experiment showed that salinity levels of 12 and $0 \mathrm{ds} / \mathrm{m}$ had the lowest $(74.3 \%)$ and highest $(83 \%)$ germination percentage, respectively. In terms of germination rate, there were significant differences between GA $\left(0.034 \mathrm{~h}^{-1}\right), \mathrm{HA}\left(0.036 \mathrm{~h}^{-1}\right)$ and Hyd $\left(0.036 \mathrm{~h}^{-1}\right)$ with $\mathrm{C}\left(0.019 \mathrm{~h}^{-}\right.$ $\left.{ }^{1}\right)$ and SA $\left(0.027 \mathrm{~h}^{-1}\right)$. Generally speaking, primed seeds germinated better than control seeds at all levels of salinity. The storability of primed seeds and control seeds had no significant decrease during storage. Finally, it was concluded that seed priming increased the tolerance to salinity stress; in terms of storability, there was no significant difference between primed seeds and primed seeds could be stored in the same way as control seeds.
\end{abstract}

Keywords: Gibberellic acid, Humic acid, Hydropriming, Salicylic acid, Stress

\section{Highlights:}

1- In the current study, the stability of prime seeds was investigated for the first time.

2- There was no significant difference between the storability of primed seeds and control seeds (unprimed) at each sampling time (the only exception was SA).

3- Primed seeds had better germination performance than the control seeds at all the salinity stress levels.

4- Seed priming treatments using gibberellic acid, humic acid and hydropriming were the best, compared with the other treatments.

DOI: $10.29252 /$ yujs.4.2.79 